\title{
$\alpha$-Tetralonyl Glucosides from the Green Walnut Husks of Juglans mandshurica and Their Antiproliferative Effects
}

\author{
Authors \\ Affiliations \\ 1 School of Traditional Chinese Medicine, Shenyang \\ Pharmaceutical University, Shenyang, People's Republic \\ of China \\ 2 School of Pharmaceutical Engineering, Shenyang Pharma- \\ ceutical University, Shenyang, People's Republic of China \\ 3 Key Laboratory of Structure-Based Drug Design \& \\ Discovery, Ministry of Education, Shenyang Pharmaceuti- \\ cal University, Shenyang, People's Republic of China
}

An-dong Wang ${ }^{1,3}$, Chao-jie Xie ${ }^{1,3}$, Yun-qiang Zhang ${ }^{1,3}$, Mei-chen $\mathrm{Li}^{1,3}$, Xia Wang ${ }^{1,3}$, Jian-yu Liu ${ }^{2,3}$, Yong-nan Xu ${ }^{2,3}$

Key words

Juglans mandshurica, Juglandaceae, in vitro, $\alpha$-tetralonyl

glucosides, antiproliferative

received September 13, 2018

revised January 1,2019

accepted January 5, 2019

Bibliography

DOI https://doi.org/10.1055/a-0832-2328

Published online January 28, 2019 | Planta Med 2019; 85:

335-339 @ Georg Thieme Verlag KG Stuttgart · New York |

ISSN 0032-0943

Correspondence

Dr. Jian-yu Liu

School of Pharmaceutical Engineering, Shenyang Pharma-

ceutical University

Wenhua Road 103, Shenyang, Liaoning 110016,

People's Republic of China

Phone: + 8615998827142

burningice@126.com
Correspondence

Prof. Yong-nan Xu

School of Pharmaceutical Engineering, Shenyang Pharma-

ceutical University

Wenhua Road 103, Shenyang, Liaoning 110016,

People's Republic of China

Phone: + 8613342452898

ynxu@syphu.edu.cn

$\circledast$

Supporting information available online at

http://www.thieme-connect.de/products

\section{ABSTRACT}

Two new $\alpha$-tetralonyl glucosides, (4S)-4,5,8-trihydroxy- $\alpha$-tetralone-5-O- $\beta$-D-glucopyranosyl $(1 \rightarrow 6)$ - $\beta$-D-glucopyranoside (1) and (4S)-4,8-dihydroxy- $\alpha$-tetralone-4-O- $\beta$-D-glucopyranosyl $(1 \rightarrow 6)$ - $\beta$-D-glucopyranoside (2), together with eight known compounds (3-10) were isolated from the green walnut husks of Juglans mandshurica. The structural characterization of all compounds was performed by spectroscopic analyses, including 1D and 2D NMR and HR-ESI-MS experiments. The isolated compounds were assayed for their cytotoxicity against two human cancer cell lines, A549 and HeLa. Four compounds (7-10) exhibited inhibitory effects against two human cancer cell lines with $\mathrm{Gl}_{50}$ values between 1.3 and $5.8 \mu \mathrm{M}$.

\section{Introduction}

Juglans, a genus of the family Juglandaceae, comprises about 20 species mainly distributed in the temperate and subtropical regions of the northern hemisphere, extending into South America [1]. Juglans mandshurica Maxim. grows in the north of China in the Heilongjiang, Jilin, Liaoning, Hebei, and Shanxi Provinces [2]. Previous phytochemical studies of J. mandshurica led to the identification of naphthoquinones, diarylheptanoids, and flavonoids (as well as their glycosides) [3-5]. The biological screening of these compounds showed promising bioactivity, including cytotoxic and antimicrobial activities [5-9].
In the course of our studies on the genus Juglans, including J. mandshurica, we have analyzed the chemical content of the green walnut husks of J. mandshurica. In particular, our attention has been focused towards the $n$-butanol-soluble fraction of the $70 \%$ ethanol extract containing naphthoquinone and diarylheptanoid components. This study led us isolate ten compounds including two new $\alpha$-tetralonyl glucosides, (4S)-4,5,8-trihydroxy$\alpha$-tetralone-5-O- $\beta$-D-glucopyranosyl $(1 \rightarrow 6)-\beta$-D-glucopyranosie (1) and (4S)-4,8-dihydroxy- $\alpha$-tetralone-4-O- $\beta$-D-glucopyranosyl $(1 \rightarrow 6)-\beta$-D-glucopyranoside $(2)$, and a series of known compounds (3-10), some of which have not been reported before from J. mandshurica ( $\bullet$ Fig. 1). These compounds were screened 
for antiproliferative activity against two human cancer cell lines, A549 and HeLa. Herein, details of the isolation, structural elucidation, and antiproliferative activities of these compounds are described.

\section{Results and Discussion}

The $70 \%$ ethanol extract of the dried the green walnut husks of J. mandshurica was subjected to multiple chromatographic steps over silica gel, Sephadex LH-20, and recycling preparative HPLC. Ten compounds were obtained, including two new compounds, (4S)-4,5,8-trihydroxy- $\alpha$-tetralone-5-O- $\beta$-D-glucopyranosyl $(1 \rightarrow 6)$ - $\beta$-D-glucopyranoside (1) (4S)-4,8-dihydroxy- $\alpha$-tetralone$4-0$ - $\beta$-D-glucopyranosyl $(1 \rightarrow 6)$ - $\beta$-D-glucopyranoside (2), and eight known compounds comprising of four naphthoquinones (3-6) and four diarylheptanoids (7-10). The structures of 1-10 were identified by physical data analyses, including 1D and 2D NMR and HR-ESI-MS. The sugar residues were identified by GC analyses after hydrolysis.

Constituents 1 and 2 are new $\alpha$-tetralonyl glucosides never described before in the literature. The full assignments of ${ }^{1} \mathrm{H}$ NMR and ${ }^{13} \mathrm{C}$ NMR spectroscopic data of the new isolated compounds (1 and 2) are listed. Their key ${ }^{1} \mathrm{H}-{ }^{1} \mathrm{H}$ COSY and HMBC correlations are presented in Fig. $\mathbf{2}$. The respective NMR and HR-ESI-MS spectra are provided in the Supporting Information.

Compound 1 was obtained as a white amorphous powder. The molecular formula of $\mathrm{C}_{22} \mathrm{H}_{30} \mathrm{O}_{14}$ was determined on the basis of the HR-ESI-MS ( $\mathrm{m} / \mathrm{z}$ 541.1524, $\left.[\mathrm{M}+\mathrm{Na}]^{+}\right)$. Acidic hydrolysis of 1 gave $\mathrm{D}$-glucose as the mono sugar residue. The ${ }^{1} \mathrm{H}$ NMR and ${ }^{13} \mathrm{C}$ NMR data of 1 exhibited signals arising from a CO group at $\delta_{C}$ 206.5, a benzene ring at $\delta_{\mathrm{H}} 7.60(1 \mathrm{H}, \mathrm{d}, J=9.0 \mathrm{~Hz}, \mathrm{H}-6), 6.93$ $(1 \mathrm{H}, \mathrm{d}, J=9.0 \mathrm{~Hz}, \mathrm{H}-7)$, two $\beta$-glucopyranosyl moieties [anomeric $\mathrm{H}$-atom at $\delta_{\mathrm{H}} 4.83\left(1 \mathrm{H}, \mathrm{d}, J=7.7 \mathrm{~Hz}, \mathrm{H}-1^{\prime}\right), 4.40(1 \mathrm{H}, \mathrm{d}, J=7.7 \mathrm{~Hz}$, $\left.\mathrm{H}-1^{\prime \prime}\right)$ and $\mathrm{C}$-atom signals at $\delta_{\mathrm{C}} 104.8\left(\mathrm{C}-1^{\prime \prime}\right), 104.2\left(\mathrm{C}-1^{\prime}\right), 78.0(\mathrm{C}$ $\left.3^{\prime \prime}\right), 77.9\left(\mathrm{C}-3^{\prime}\right), 77.8\left(\mathrm{C}-5^{\prime \prime}\right), 77.4\left(\mathrm{C}-5^{\prime}\right), 75.2\left(\mathrm{C}-2^{\prime}\right), 75.1\left(\mathrm{C}-2^{\prime \prime}\right)$, $71.6\left(\mathrm{C}-4^{\prime \prime}\right), 71.3\left(\mathrm{C}-4^{\prime}\right), 70.0\left(\mathrm{C}-6^{\prime}\right)$, and $\left.62.7\left(\mathrm{C}-6^{\prime \prime}\right)\right]$. These NMR characteristics resembled those observed for 3 [10]. However, instead of a $\beta$-glucopyranosyl moiety in 3 , compound 1 had two $\beta$ glucopyranosyl moieties in view of the anomeric $\mathrm{H}$-atom at $\delta_{\mathrm{H}}$ $4.83\left(1 \mathrm{H}, \mathrm{d}, J=7.7 \mathrm{~Hz}, \mathrm{H}-1^{\prime}\right), 4.40\left(1 \mathrm{H}, \mathrm{d}, J=7.7 \mathrm{~Hz}, \mathrm{H}-1^{\prime \prime}\right)$. The linkage of the second sugar moiety at $\mathrm{OH}-\mathrm{C}\left(6^{\prime}\right)$ of the first sugar moiety was established from the HMBC correlations between $\delta_{\mathrm{H}}$ $4.40\left(1 \mathrm{H}, \mathrm{d}, J=7.7 \mathrm{~Hz}, \mathrm{H}-1^{\prime \prime}\right)$ and $\delta_{\mathrm{C}} 70.0\left(\mathrm{C}-6^{\prime}\right)$. The absolute configuration of the saccharides was determined to be D-glucose by GC analysis of chiral derivatives in the hydrolysate of this compound. As for the absolute configuration of the chiral carbon, (4S)-1 was determined on the basis of a negative Cotton effect at ca. 220-240 nm in the CD spectrum of 1 (Fig. 2S, Supporting Information) and comparison of its optical rotation $\left([\alpha]_{D}^{20}:-45\right.$ in $\mathrm{MeOH}$ ) with that of literature [11].

After further comprehensive analysis of its NMR spectra (Figs. 3S-8S, Supporting Information), compound 1 was identified as (4S)-4,5,8-trihydroxy- $\alpha$-tetralone-5-O- $\beta$-D-glucopyranosyl $(1 \rightarrow 6)$ - $\beta$-D-glucopyranoside.

Compound 2 was obtained as a white amorphous powder. The molecular formula of $\mathrm{C}_{22} \mathrm{H}_{30} \mathrm{O}_{13}$ was determined on the basis of the HR-ESI-MS ( $\mathrm{m} / \mathrm{z}$ 525.1563, $\left.[\mathrm{M}+\mathrm{Na}]^{+}\right)$. Acidic hydrolysis of 2

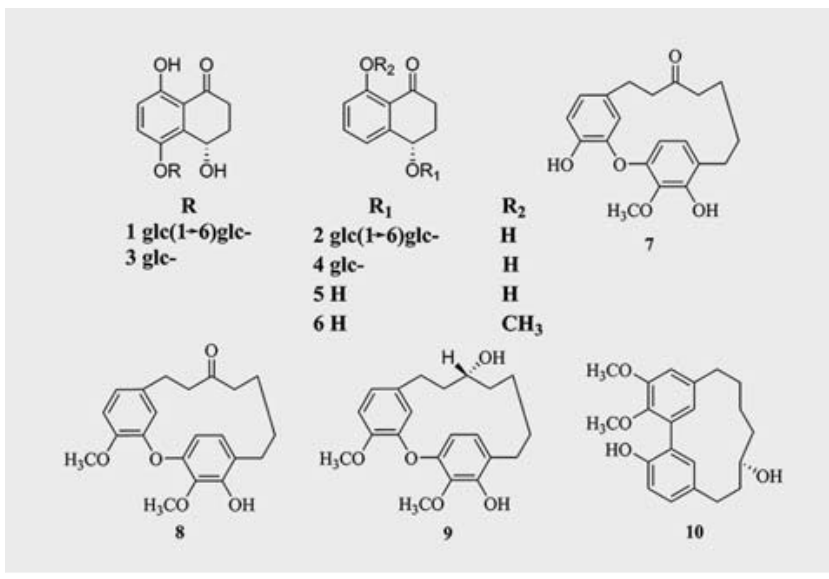

- Fig. 1 Chemical structures of compounds 1-10 from the green walnut husks of $J$. mandshurica.

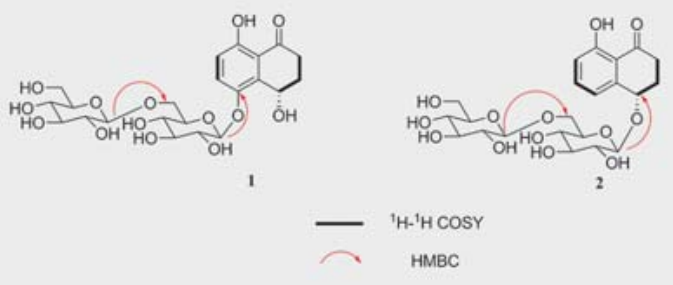

- Fig. 2 The key ${ }^{1} \mathrm{H}-{ }^{1} \mathrm{H}$ COSY and $\mathrm{HMBC}$ of compounds $1-2$.

gave D-glucose as the mono sugar residue. The ${ }^{1} \mathrm{H}$ NMR and ${ }^{13} \mathrm{C}$ NMR data of 2 exhibited the signals arising from a $\mathrm{CO}$ group at $\delta_{\mathrm{C}}$ 206.6, a benzene ring at $\delta_{\mathrm{H}} 7.53(1 \mathrm{H}, \mathrm{t}, J=8.4 \mathrm{~Hz}, \mathrm{H}-6), 7.21$ $(1 \mathrm{H}, \mathrm{d}, J=7.4 \mathrm{~Hz}, \mathrm{H}-5), 6.92(1 \mathrm{H}, \mathrm{dd}, J=8.4,1.0 \mathrm{~Hz}, \mathrm{H}-7)$, two $\beta$ glucopyranosyl moieties [anomeric $\mathrm{H}$-atom at $\delta_{\mathrm{H}} 4.47(1 \mathrm{H}, \mathrm{d}$, $\left.\left.J=7.8 \mathrm{~Hz}, \mathrm{H}-1^{\prime \prime}\right), 4.39\left(1 \mathrm{H}, \mathrm{d}, J=7.7 \mathrm{~Hz}, \mathrm{H}-1^{\prime}\right)\right]$ and $\mathrm{C}$-atom signals at $\delta_{\mathrm{C}} 105.1\left(\mathrm{C}-1^{\prime \prime}\right), 102.7\left(\mathrm{C}-1^{\prime}\right), 78.1\left(\mathrm{C}-5^{\prime \prime}\right), 78.0\left(\mathrm{C}-3^{\prime}\right), 78.0$ (C3"), 77.1 (C-5'), 75.2 (C-2'), 75.1 (C-2"), 71.7 (C-4"), $71.6\left(\mathrm{C}-4^{\prime}\right)$, $70.1\left(\mathrm{C}-6^{\prime}\right)$, and $62.8\left(\mathrm{C}-6^{\prime \prime}\right)$. These NMR characteristics resembled those observed for 4 [12]. However, instead of a $\beta$-glucopyranosyl moiety in 4 , compound 2 had two $\beta$-glucopyranosyl moieties in view of the anomeric $\mathrm{H}$-atom at $\delta_{\mathrm{H}} 4.47(1 \mathrm{H}, \mathrm{d}, J=7.8 \mathrm{~Hz}, \mathrm{H}-1 ")$, $4.39\left(1 \mathrm{H}, \mathrm{d}, \mathrm{J}=7.7 \mathrm{~Hz}, \mathrm{H}-1^{\prime}\right)$. The linkage of the second sugar moiety at $\mathrm{OH}-\mathrm{C}\left(6^{\prime}\right)$ of the first sugar moiety was established from the HMBC correlations between $\delta_{\mathrm{H}} 4.47\left(1 \mathrm{H}, \mathrm{d}, J=7.8 \mathrm{~Hz}, \mathrm{H}-1^{\prime \prime}\right)$ and $\delta_{\mathrm{C}} 70.1\left(\mathrm{C}-6^{\prime}\right)$. The absolute configuration of the saccharides was determined to be D-glucose by GC analysis of the chiral derivatives in the hydrolysate of this compound. As for the absolute configuration of the chiral carbon, (4S)-2 was determined on the basis of a negative Cotton effect at ca. 210-230 nm in the CD spectrum of 2 (Fig. 10S, Supporting Information) and comparison of its optical rotation $\left([\alpha]_{\mathrm{D}}^{20}:-51\right.$ in $\left.\mathrm{MeOH}\right)$ with that of the literature [11].

After further comprehensive analysis of its NMR spectra (Figs. 11S-16S, Supporting Information), compound 2 was identified as (4S)-4,8-dihydroxy- $\alpha$-tetralone-4-O- $\beta$-D-glucopyranosyl $(1 \rightarrow 6)$ - $\beta$-D-glucopyranoside. 

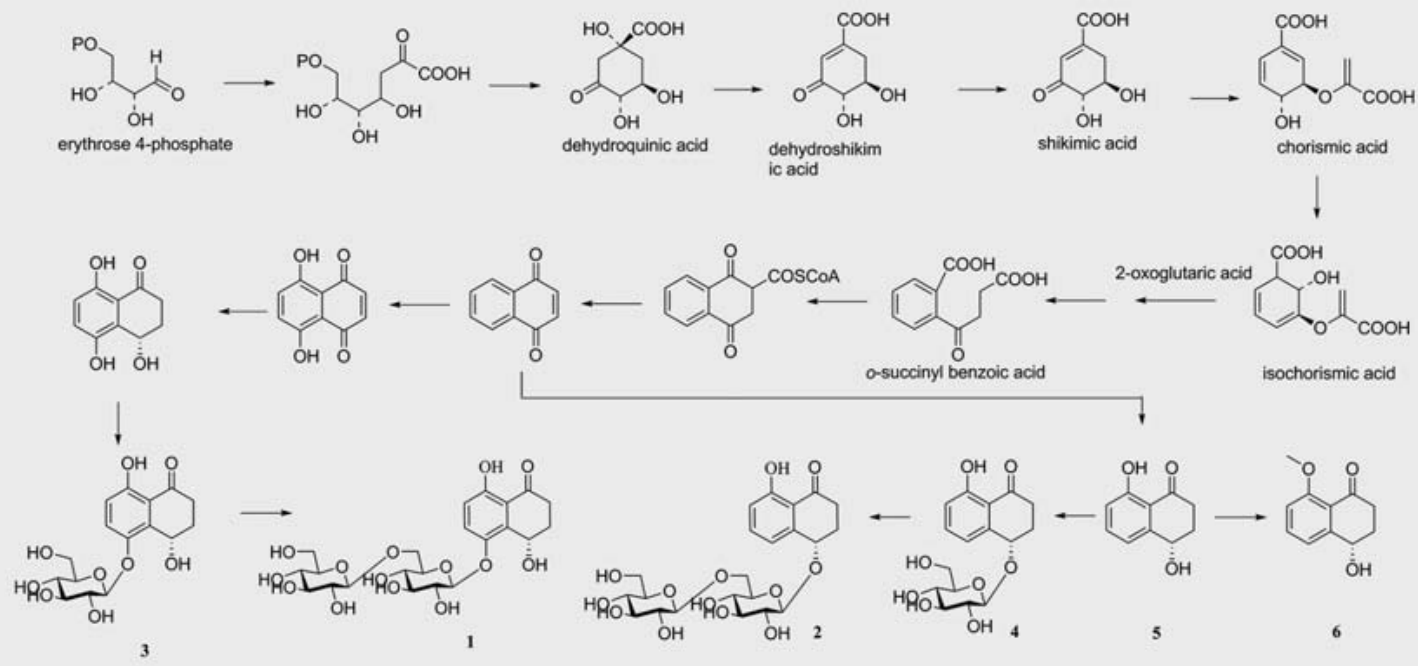

- Fig. 3 Plausible biosynthetic pathway of new compounds.

$\alpha$-Tetralonyl glucosides with one $\beta$-glucopyranosyl moiety have been reported from the green walnut husks of $J$. mandshurica before. But the naphthoquinone with two $\beta$-glucopyranosyl moieties has not been described in the literature so far. The putative biosynthetic pathway begins from erythrose-4-phosphate, which was derived through a series of reactions, including intermolecular cyclization, oxidation, hydroxylation, and glycosylation ( $\bullet$ Fig. 3). The eight known compounds identified by comparing their spectroscopic and spectrometric data (NMR and HRESIMS) with those in the literature are juglanoside $E(3)$ [10], berchemiaside $A$ (4) [12], regiolone (5) [13], berchemiaside B (6), 2-oxatrycyclo[13.2.2.13,7] eicosa-3,5,7-(20), 15,17,18-hexaen-10-one (7), juglanin A (8), 2-oxatrycyclo[13.2.2.13,7]eicosa-3,5,7(20),15,17, 18-hexaen-10-16-diol (9), and (11S)-11,17-dihydroxy-3,4-dimethoxy-[7,0]-metacyclophane $(10)[3,14,15]$. Copies of the original spectra for the known compounds are obtainable from the corresponding author.

All J. mandshurica components isolated were tested for their cytotoxic activity against A549 and HeLa cell lines, with etoposide as the positive control ( $\bullet$ Table 1 ). Compounds $1-6$ showed no or weak cytotoxic activity, whereas compounds $7-10$ exerted strong cytotoxicity with $\mathrm{Gl}_{50}$ values in the range of $1.3-5.8 \mu \mathrm{M}$. Based on the available data, it seems that diarylheptanoids (compounds 710) are favorable for the observed cytotoxic activity.

Diarylheptanoid is a group of compounds that bears the 1,7-dihenylheptane skeleton as a special characteristic in the natural product estate [16]. Since the first diarylheptanoid isolated in 1815 , approximately 400 such materials have been obtained from natural resources [17]. Hirsutanone and oregonin, from Alnus japonica Steud, exhibited potent antiproliferative activity against two colon cancer cell lines (HCT-15 and Colo205) [18]. Tian et al. had suggested that a diarylheptanoid, 1-(4-hydroxy-3-methoxyphenyl)-7-(3,4-dihydroxyphenyl)-4E-en-3-heptanone, was isolated from Alpinia officinarum and provided new insight into neuroblastoma chemotherapy [19]. Furthermore, diarylheptanoids
- Table 1 Cytotoxicity data of isolated compounds $1-10 .^{\text {a }}$

\begin{tabular}{|c|c|c|}
\hline Compound & $\mathrm{Gl}_{\mathbf{5 0}}(\boldsymbol{\mu M})$ & HeLa \\
\hline $\mathbf{1}$ & $\mathbf{A 5 4 9}$ & 73.6 \\
\hline $\mathbf{2}$ & 51.1 & 51.9 \\
\hline $\mathbf{3}$ & 67.6 & 70.2 \\
\hline $\mathbf{4}$ & $>100$ & $>100$ \\
\hline $\mathbf{5}$ & $>100$ & $>100$ \\
\hline $\mathbf{6}$ & 36.4 & 81.4 \\
\hline $\mathbf{7}$ & 61.6 & 2.1 \\
\hline $\mathbf{8}$ & 1.6 & 3.3 \\
\hline $\mathbf{9}$ & 5.8 & 1.9 \\
\hline $\mathbf{1 0}$ & 2.4 & 2.7 \\
\hline Etoposide & 1.3 & 0.7 \\
\hline
\end{tabular}

A549: human lung cancer cell lines. HeLa: human cervical carcinoma cancer cell lines. aData expressed as $\mathrm{GI}_{50}$ values $(\mu \mathrm{M})$; b positive control

have been reported by numerous studies to possess diverse bioactivities, including anti-inflammatory [20] and antiemetic [21].

In summary, two new $\alpha$-tetralonyl glucosides (1 and 2 ) and eight known compounds (3-10) were isolated from the green walnut husks of $\mathrm{J}$. mandshurica, and the structures were determined by MS, 1D NMR, and 2D NMR. The results obtained in this study show that diarylheptanoids (7-10) exhibited inhibitory effects against the two human cancer cell lines (A549 and HeLa) with $\mathrm{GI}_{50}$ values below $6 \mu \mathrm{M}$, while naphthoquinones (1-6) were inactive. 


\section{Material and Methods}

\section{General experimental procedures}

The NMR spectra were measured in methanol- $d_{4}$ on a Bruker ARX400 or AV600 instrument with TMS as an internal standard. The CD spectrum was tested using a JASCO pu-2080 spectrometer. IR spectra were taken on a Bruker IFS-55 infrared spectrophotometer with a $\mathrm{KBr}$ disk. Optical rotations were measured on a PekingElmer $241 \mathrm{MC}$ Spectropolarimeter at $20^{\circ} \mathrm{C}$. ESI-MS spectra were recorded on a Waters Quattro micro API LC/MS/MS spectrometer (Waters). HR-TOF-MS spectra were performed on an Agilent LC/ MS spectrometer (Agilent). HPLC was performed on JAI LC9103 Recycling preparative HPLC (Japan Analytical Industries) equipped with JAIGEL-ODS-AP-P column and JAIGEL-GS310 column using a JAI refractive index detector and a JAI UV-3702 detector with MultiChro 2000 workstation. TLC was performed on precoated $\mathrm{GF}_{254}$ plates (Merck) and detected by spraying with $10 \% \mathrm{H}_{2} \mathrm{SO}_{4}$ followed by heating.

\section{Plant material}

The green walnut husks of J. mandshurica were collected in October 2014 at Yichun, Heilongjiang, China, and authenticated by Professor Jin-cai Lu (The School of Traditional Chinese Materia Medica, Shenyang Pharmaceutical University). A voucher specimen (No. 1014023) is stored at the key laboratory of Modern Analysis of TCM, School of Pharmacy, Shenyang Pharmaceutical University, Shenyang, China.

\section{Extraction and isolation}

The green walnut husks of J. mandshurica $(20 \mathrm{~kg})$ were extracted with $70 \%(v / v)$ aqueous ethanol three times $(3 \times 80 \mathrm{~L})$ to give $1 \mathrm{~kg}$ of crude extract. The crude extract was suspended in $3 \mathrm{~L}$ of water. The suspension was successively partitioned with EtOAc $(3 \times 3 \mathrm{~L})$ and $n-\mathrm{BuOH}(3 \times 3 \mathrm{~L})$. The $n-\mathrm{BuOH}$-soluble fraction $(120 \mathrm{~g})$ was subjected to silica gel chromatography, eluting with gradients of $\mathrm{CH}_{2} \mathrm{Cl}_{2}$ : $\mathrm{MeOH}(100: 13000 \mathrm{~mL}, 100: 33000 \mathrm{~mL}, 100: 73000 \mathrm{~mL}$, $100: 153000 \mathrm{~mL}, 100: 303000 \mathrm{~mL}, 100: 703000 \mathrm{~mL}$ ) on a silica gel column (column dimension: $6.0 \times 80 \mathrm{~cm}$ ) to give six fractions, Fr. A-F (4.7 g, $6.3 \mathrm{~g}, 12.2 \mathrm{~g}, 8.4 \mathrm{~g}, 8.1 \mathrm{~g}$, and $3.0 \mathrm{~g})$. Fraction A was purified by silica gel CC (column dimension: $2.5 \times 40 \mathrm{~cm}$ ) with $\mathrm{CH}_{2} \mathrm{Cl}_{2}$ : $\mathrm{MeOH}$ (300:11000 mL, 150:3800 mL, 100:11000 mL) to afford $230 \mathrm{mg}$ of Fr. A-1 and $130 \mathrm{mg}$ of Fr. A-2. Fraction A-1 was purified by recycling preparative $\mathrm{HPLC}$ with $\mathrm{MeOH}-\mathrm{H}_{2} \mathrm{O}$ (85:15) as the eluent to obtain pure compound 7 (23.1 mg, $t_{R}$ 43 min). Fraction A-2 was purified by recycling preparative HPLC with $\mathrm{MeOH}-\mathrm{H}_{2} \mathrm{O}(85: 15)$ as the eluent to obtain pure compounds 8 (15.3 mg, $\left.t_{R} 34 \mathrm{~min}\right)$ and $9\left(30.1 \mathrm{mg}, t_{\mathrm{R}} 38 \mathrm{~min}\right)$. Fraction $B$ was purified by silica gel CC (column dimension: $2.5 \times 40 \mathrm{~cm}$ ) with $\mathrm{CH}_{2} \mathrm{Cl}_{2}$ : $\mathrm{MeOH}(100: 11000 \mathrm{~mL}, 100: 21000 \mathrm{~mL}, 100: 31000 \mathrm{~mL}$ ) to afford $400 \mathrm{mg}$ of Fr. B-1. Fraction B-1 was purified by recycling preparative $\mathrm{HPLC}$ with $\mathrm{MeOH}-\mathrm{H}_{2} \mathrm{O}(70: 30)$ as the eluent to obtain pure compounds 5 ( $9.1 \mathrm{mg}, t_{R} 29 \mathrm{~min}$ ) and 6 (6.2 mg, $\left.t_{\mathrm{R}} 35 \mathrm{~min}\right)$. Fraction $C$ was purified by silica gel CC (column dimension: $2.5 \times$ $40 \mathrm{~cm}$ ) with $\mathrm{CH}_{2} \mathrm{Cl}_{2}: \mathrm{MeOH}(100: 31000 \mathrm{~mL}, 100: 51000 \mathrm{~mL}$, $100: 81000 \mathrm{~mL}$ ) to afford $210 \mathrm{mg}$ of Fr. C-1 and $310 \mathrm{mg}$ of Fr. C2. Fraction $\mathrm{C}-1$ was purified by recycling preparative HPLC with
$\mathrm{MeOH}-\mathrm{H}_{2} \mathrm{O}(55: 45)$ as the eluent to obtain pure compounds 1 $\left(10.5 \mathrm{mg}, t_{\mathrm{R}} 21 \mathrm{~min}\right)$ and $3\left(9.0 \mathrm{mg}, t_{\mathrm{R}} 25 \mathrm{~min}\right)$. Fraction $\mathrm{C}-2$ was purified by recycling preparative HPLC with $\mathrm{MeOH}-\mathrm{H}_{2} \mathrm{O}(55: 45)$ as the eluent to obtain pure compounds 2 (17.7 $\left.\mathrm{mg}, t_{\mathrm{R}} 24 \mathrm{~min}\right)$, 4 (8.7 mg, $\left.t_{R} 31 \mathrm{~min}\right)$, and 10 (7.9 mg, $\left.t_{\mathrm{R}} 35 \mathrm{~min}\right)$.

\section{(4S)-4,5,8-Trihydroxy- $\alpha$-tetralone-5-O- $\beta$-D-gluco- pyranosyl $(1 \rightarrow 6)$ - $\beta$-D-glucopyranoside (1)}

White amorphous power, $[\alpha]_{D}^{20}=-45$ (c 0.6, MeOH); HR-ESI-MS: $\mathrm{m} / \mathrm{z}$ 541.1524, $[\mathrm{M}+\mathrm{Na}]^{+}$(calcd. for $\left.\mathrm{C}_{22} \mathrm{H}_{30} \mathrm{O}_{14} \mathrm{Na}, 541.1523\right) .{ }^{1} \mathrm{H}$ NMR $\left(600 \mathrm{MHz}\right.$, methanol- $\left.d_{4}\right) \delta 7.60(1 \mathrm{H}, \mathrm{d}, J=9.0 \mathrm{~Hz}, \mathrm{H}-6), 6.93$ $(1 \mathrm{H}, \mathrm{d}, J=9.0 \mathrm{~Hz}, \mathrm{H}-7), 5.37(1 \mathrm{H}, \mathrm{d}, J=2.7 \mathrm{~Hz}, \mathrm{H}-4), 4.83(1 \mathrm{H}, \mathrm{d}$, $\left.J=7.7 \mathrm{~Hz}, \mathrm{H}-1^{\prime}\right), 4.40\left(1 \mathrm{H}, \mathrm{d}, J=7.7 \mathrm{~Hz}, \mathrm{H}-1^{\prime \prime}\right), 4.21(1 \mathrm{H}, \mathrm{dd}$, $\left.J=11.7,1.9 \mathrm{~Hz}, \mathrm{H}-6^{\prime}{ }_{\mathrm{a}}\right), 3.88\left(1 \mathrm{H}, \mathrm{dd}, J=11.9,2.1 \mathrm{~Hz}, \mathrm{H}-6^{\prime \prime}{ }_{\mathrm{a}}\right), 3.83$ $\left(1 \mathrm{H}, \mathrm{dd}, J=11.7,6.2 \mathrm{~Hz}, \mathrm{H}-6^{\prime}{ }_{\mathrm{b}}\right), 3.66\left(2 \mathrm{H}, \mathrm{m}, \mathrm{H}-5^{\prime} / \mathrm{H}-6^{\prime \prime}{ }_{\mathrm{b}}\right), 3.56$ $\left(1 \mathrm{H}, \mathrm{t}, J=9.0 \mathrm{~Hz}, \mathrm{H}-2^{\prime}\right), 3.49\left(1 \mathrm{H}, \mathrm{t}, J=9.0 \mathrm{~Hz}, \mathrm{H}-5^{\prime \prime}\right), 3.44(1 \mathrm{H}, \mathrm{t}$, $\left.J=9.0 \mathrm{~Hz}, \mathrm{H}-4^{\prime}\right), 3.37\left(1 \mathrm{H}, \mathrm{t}, J=9.0 \mathrm{~Hz}, \mathrm{H}-3^{\prime}\right), 3.31(1 \mathrm{H}, \mathrm{d}$, $\left.J=9.0 \mathrm{~Hz}, \mathrm{H}-4^{\prime \prime}\right), 3.26\left(2 \mathrm{H}, \mathrm{m}, \mathrm{H}-2^{\prime \prime} / \mathrm{H}-3^{\prime \prime}\right), 3.08(1 \mathrm{H}$, ddd, $J=17.4,12.7,6.0 \mathrm{~Hz}, \mathrm{H}-2 \mathrm{a}), 2.56(1 \mathrm{H}, \mathrm{d}, J=17.4 \mathrm{~Hz}, \mathrm{H}-2 \mathrm{~b}), 2.26$ $(1 \mathrm{H}, \mathrm{m}, \mathrm{H}-3 \mathrm{a}), 2.24(1 \mathrm{H}, \mathrm{m}, \mathrm{H}-3 \mathrm{~b}) .{ }^{13} \mathrm{C}$ NMR $(100 \mathrm{MHz}$, methanol-d 4 ) $\delta 206.5$ (C-1), 159.0 (C-8), 148.7 (C-5), 134.5 (C-4a), 128.5 (C-6), 119.2 (C-7), 116.1 (C-8a), 104.8 (C-1"), 104.2 (C$\left.1^{\prime}\right), 78.0\left(\mathrm{C}-3^{\prime \prime}\right), 77.9\left(\mathrm{C}-3^{\prime}\right), 77.8\left(\mathrm{C}-5^{\prime \prime}\right), 77.4\left(\mathrm{C}-5^{\prime}\right), 75.2\left(\mathrm{C}-2^{\prime}\right)$, $75.1\left(\mathrm{C}-2^{\prime \prime}\right), 71.6\left(\mathrm{C}-4^{\prime \prime}\right), 71.3\left(\mathrm{C}-4^{\prime}\right), 70.0\left(\mathrm{C}-6^{\prime}\right), 62.7\left(\mathrm{C}-6^{\prime \prime}\right), 61.3$ (C-4), 33.6 (C-2), 30.2 (C-3).

\section{(4S)-4,8-Dihydroxy- $\alpha$-tetralone-4- $O-\beta$-D-gluco- pyranosyl $(1 \rightarrow 6)$ - $\beta$-D-glucopyranoside (2)}

White amorphous power, $[\alpha]_{\mathrm{D}}^{20}=-51$ ( 0.6 , MeOH); HR-ESI-MS: $\mathrm{m} / \mathrm{z}$ 525.1563, [M + Na] $]^{+}$(calcd. for $\left.\mathrm{C}_{22} \mathrm{H}_{30} \mathrm{O}_{13} \mathrm{Na}, 525.1570\right) .{ }^{1} \mathrm{H}$ NMR $\left(600 \mathrm{MHz}\right.$, methanol- $\left.d_{4}\right) \delta 7.53(1 \mathrm{H}, \mathrm{t}, J=8.4 \mathrm{~Hz}, \mathrm{H}-6), 7.21$ $(1 \mathrm{H}, \mathrm{d}, J=7.4 \mathrm{~Hz}, \mathrm{H}-5), 6.92(1 \mathrm{H}, \mathrm{dd}, J=8.4,1.0 \mathrm{~Hz}, \mathrm{H}-7), 5.07$ $(1 \mathrm{H}, \mathrm{t}, J=6.3 \mathrm{~Hz}, \mathrm{H}-4), 4.47\left(1 \mathrm{H}, \mathrm{d}, J=7.8 \mathrm{~Hz}, \mathrm{H}-1^{\prime \prime}\right), 4.39(1 \mathrm{H}, \mathrm{d}$, $\left.J=7.7 \mathrm{~Hz}, \mathrm{H}-1^{\prime}\right), 4.23\left(1 \mathrm{H}, \mathrm{dd}, J=11.7,2.0 \mathrm{~Hz}, \mathrm{H}-6^{\prime}{ }_{\mathrm{a}}\right), 3.92(1 \mathrm{H}$, $\left.\mathrm{dd}, J=11.8,1.8 \mathrm{~Hz}, \mathrm{H}-6^{\prime \prime}{ }_{\mathrm{a}}\right), 3.83\left(1 \mathrm{H}, \mathrm{dd}, J=11.7,6.5 \mathrm{~Hz}, \mathrm{H}-6^{\prime}{ }_{\mathrm{b}}\right)$, $3.71\left(1 \mathrm{H}, \mathrm{dd}, J=11.8,5.1 \mathrm{~Hz}, \mathrm{H}-6^{\prime \prime}{ }_{\mathrm{b}}\right), 3.51(1 \mathrm{H}, \mathrm{ddt}, J=8.4,4.2$, $\left.1.9 \mathrm{~Hz}, \mathrm{H}-5^{\prime}\right), 3.39\left(1 \mathrm{H}, \mathrm{m}, \mathrm{H}-3^{\prime \prime}\right), 3.34\left(4 \mathrm{H}, \mathrm{m}, \mathrm{H}-3^{\prime} / \mathrm{H}-4^{\prime} / \mathrm{H}-4^{\prime \prime} \mid\right.$ H-5"), $3.28\left(2 \mathrm{H}, \mathrm{t}, J=9.0 \mathrm{~Hz}, \mathrm{H}-2^{\prime} / \mathrm{H}-2^{\prime \prime}\right), 3.11(1 \mathrm{H}, \mathrm{ddd}, J=17.9$, 9.6, $5.0 \mathrm{~Hz}, \mathrm{H}-2 \mathrm{a}), 2.69(1 \mathrm{H}, \mathrm{ddd}, J=17.9,6.3,4.8 \mathrm{~Hz}, \mathrm{H}-3 \mathrm{~b})$, $2.40(1 \mathrm{H}, \mathrm{m}, \mathrm{H}-3 \mathrm{a}), 2.34$ (1H, m, H-3b). ${ }^{13} \mathrm{C} \mathrm{NMR}(100 \mathrm{MHz}$, methanol-d 4 ) $\delta 206.6$ (C-1), 163.8 (C-8), 144.1 (C-4a), 137.5 (C-6), 120.7 (C-5), 118.6 (C-7), 116.8 (C-8a), 105.1 (C-1"), 102.7 (C$\left.1^{\prime}\right), 78.1$ (C-5"), 78.0 (C-3'), 78.0 (C-3"), 77.1 (C-5'), $75.2\left(\mathrm{C}-2^{\prime}\right)$, 75.1 (C-2" ), 74.7 (C-4), $71.7\left(\mathrm{C}-4^{\prime \prime}\right), 71.6\left(\mathrm{C}-4^{\prime}\right), 70.1\left(\mathrm{C}-6^{\prime}\right), 62.8$ (C-6"), $35.2(\mathrm{C}-2), 31.1$ (C-3).

\section{Acid hydrolysis of compounds 1 and 2}

Each compound $(2 \mathrm{mg})$ was treated with $1 \mathrm{M} \mathrm{HCl}(4 \mathrm{~mL})$ at $90^{\circ} \mathrm{C}$ for $2 \mathrm{~h}$. Then the reaction mixture was extracted with $\mathrm{CHCl}_{3}$ $(3 \times 5 \mathrm{~mL})$. The aqueous layer was collected and the water was evaporated under vacuum with the repeated addition of $\mathrm{MeOH}$ to remove the solvent completely. The residue was redissolved in anhydrous pyridine $(2 \mathrm{~mL})$ and mixed with a pyridine solution of $L$ cysteine methyl ester hydrochloride $(2 \mathrm{~mL})$. After the mixed solution was heated at $60^{\circ} \mathrm{C}$ for $1 \mathrm{~h}$, trimethylchlorosilane $(0.5 \mathrm{~mL})$ was added and the resulting mixture was stirred at $60^{\circ} \mathrm{C}$ for another 30 min. Then, the solution was concentrated to dryness 
and taken up in water $(3 \times 1 \mathrm{~mL})$, followed by extraction with $n$ hexane $(3 \times 1 \mathrm{~mL})$. The supernatant was analyzed by GC. Separations were carried out on HP-5 columns $(320 \mu \mathrm{m} \times 30 \mathrm{~cm}$, $0.25 \mu \mathrm{m})$. Highly pure $\mathrm{N}_{2}$ was employed as a carrier gas $(1.0 \mathrm{~mL} /$ $\mathrm{min}$ ), and the FID detector operated at $280^{\circ} \mathrm{C}$ (column temperature $160-200^{\circ} \mathrm{C}$ ). The retention time of the monosaccharide derivative was as follows: $D$-glucose (14.43 $\mathrm{min})$.

\section{Cell culture}

Human lung cancer cells (A549) and human cervical carcinoma cancer cells (HeLa) was provided by the ATCC. The cells were cultured in medium (RPMI 1640 for A549 and DMEM for HeLa) supplemented with $10 \%$ heat-inactivated FBS and antibiotics/antimycotics (PSF; 100 units/mL penicillin G sodium, $100 \mu \mathrm{g} / \mathrm{mL}$ streptomycin, and $250 \mathrm{ng} / \mathrm{mL}$ amphotericin B). The cells were incubated at $37^{\circ} \mathrm{C}$ and $5 \% \mathrm{CO}_{2}$ in a humidified atmosphere. Etoposide (purity $>98 \%$; Sigma) was used as a positive control.

\section{In vitro cell proliferation assay}

Cell viability was determined by the sulforhodamine B (SRB) protein staining method. Cells were seeded in 96-well plates and incubated for $24 \mathrm{~h}$, and then fixed (for zero day controls) or treated with the test compounds for $72 \mathrm{~h}$. All compounds were solved in DMSO (final concentration of $0.1 \%[\mathrm{v} / \mathrm{v}]$ ), stored at $-20^{\circ} \mathrm{C}$, and diluted to the desired concentration $(0.01,0.1,1,10,100 \mu \mathrm{M})$ in normal saline immediately prior to each experiment. Each concentration was tested thrice. At least three experiments were performed. Data leading to the determination of $\mathrm{GI}_{50}$ values are provided as dose-response curves in Fig. 17S, Supporting Information. After incubation, cells were fixed with $10 \%$ trichloroacetic acid (TCA), dried, and stained in $0.4 \%$ SRB in $1 \%$ acetic acid solution. Unbound dye was washed, and stained cells were dried and dissolved in $10 \mathrm{mM}$ Tris $(\mathrm{pH} 10.0)$. Absorbance was measured at $515 \mathrm{~nm}$ and cell proliferation was determined as follows: cell proliferation $(\%)$ = (average absorbance compound $_{\text {- average } a b-}$ sorbance $\left._{\text {zero day }}\right) /\left(\right.$ average absorbance ${ }_{\text {control }}$ - average absorbance $\left._{\text {zero day }}\right) \times 100 \%$. $\mathrm{Gl}_{50}$ values were calculated by nonlinear regression analysis using Table Curve 2D software (Version 5.01, Systat Software Inc.).

\section{Supporting information}

The NMR and HR-ESI-MS spectra of compounds 1 and 2 and graphs showing dose-response curves for the investigated compounds are provided as Supporting Information.

\section{Acknowledgements}

This work was supported by the General Project of the Department of Education of Liaoning Province (grant no. 201610163L13) and the Natural Science Foundation of Liaoning Province (grant no. 201602712).

\section{Conflict of Interest}

The authors declare no conflict of interest.

\section{References}

[1] Lin H, Zhang YW, Bao YL, Wu Y, Sun LG, Yu CL, Huang YX, Wang EB, Li YX. Secondary metabolites from the stem bark of Juglans mandshurica. Biochem Syst Ecol 2013; 51: 184-188

[2] Editorial Committee of Flora of China, Chinese Academy of Sciences. Flora of China, Vol. 21. Beijing: Science Press; 1979: 31-33

[3] Liu JX, Di DL, Wei XN, Han Y. Cytotoxic diarylheptanoids from the pericarps of walnuts (Juglans regia). Planta Med 2008; 74: 754-759

[4] Zhao H, Bai H, Jing Y, Li W, Yin S, Zhou H. A pair of taxifolin-3-O-arabinofuranoside isomers from Juglans regia L. Nat Prod Res 2016; 31: 945-950

[5] Yu HY, Zhang XQ, Li X, Zeng FB, Ruan HL. 2-methoxyjuglone induces apoptosis in HepG2 human hepatocellular carcinoma cells and exhibits in vivo antitumor activity in a $\mathrm{H} 22$ mouse hepatocellular carcinoma model. J Nat Prod 2013; 76: 889-895

[6] Guo LN, Zhang R, Guo XY, Cui T, Dong W, Huo JH, Wang WM. Identification of new naphthalenones from Juglans mandshurica and evalution of their anticancer activities. Chin J Nat Medicines 2015; 13: 707-710

[7] Yu HY, Li X, Meng FY, Pi HF, Zhang P, Ruan HL. Naphthoquinones from the root barks of Juglans cathayensis dode. J Asian Nat Prod Res 2011; 13: $581-587$

[8] Jin M, Sun J, Li R, Diao S, Zhang C, Cui J, Son JK, Zhou W, Li G. Two new quinones from the roots of Juglans mandshurica. Arch Pharm Res 2016; 39: $1237-1241$

[9] Li ], Xu KP, Zou ZX, Zou H, Long HP, Tan LH, Liu RH, Wang YK, Xu PS, Tan GS. Two new compounds from the green peel of Juglans mandshurica. J Asian Nat Prod Res 2017; 19: 1087-1092

[10] Liu L, Li W, Koile K, Zhang S, Nikado T. New $\alpha$-tetralonyl glucosides from the fruit of Juglans mandshurica. Chem Pharm Bull 2004; 52: 566-569

[11] Machida K, Matsuoka E, Kasahara T, Kikuchi M. Studies on the constituents of Juglans species. I. Structural determination of (4S)- and (4R)-4hydroxy-a-tetralone derivatives from the fruit of Juglans mandshurica MAXIM. var. sieboldiana MAKINO. Chem Pharm Bull 2005; 53: 934-937

[12] Fujimoto H, Nagano J, Yamaguchi K, Yamazaki M. Immunosuppressive components from an Ascomycete, Diplogelasinospora grovesii. Chem Pharm Bull 1998; 46: 423-429

[13] Talapatra S, Karmacharya B, Talapatra B. (-)-Regilone, an $\alpha$-tetralone from Juglans Regia: structure, stereochemistry and conformation. Phytochemistry 1988; 27: 3929-3932

[14] Jin W, Cai X, Na M, Lee J, Bae K. Triterpenoids and diarylheptanoids from Alnus hirsuta inhibit HIF-1 in AGS cells. Arch Pharm Res 2007; 30: 412418

[15] Yao D, Jin M, Zhang C, Luo J, Li R, Zheng M, Cui J, Li G. A new phenolic glycoside from Juglans mandshurica. Nat Prod Res 2014; 28: 998-1002

[16] Lv H, She G. Naturally occurring diarylheptanoids - a supplementary version. Rec Nat Prod 2012; 6: 321-333

[17] Alberti A, Riethmuller E, Beni S. Characterization of diarylheptanoids: an emerging class of bioactive natural products. J Pharmaceut Biomed 2018; 147: 13-34

[18] Uto T, Tung NH, Appiah OR, Aning A, Morinaga O, Edoh D, Nyarko AK, Shoyama Y. Antiproliferative and pro-apoptotic activity of diarylheptanoids isolated from the bark of Alnus japonica in human leukemia cell lines. Am J Chinese Med 2015; 43: 757-767

[19] Tian Z, An N, Zhou B, Xiao P, Kohane IS, Wu E. Cytotoxic diarylheptanoid induces cell cycle arrest and apoptosis via increasing ATF3 and stabilizing p53 in SH-SY5Y cells. Cancer Chemother Pharmacol 2009; 63: 11311139

[20] Lai YC, Chen CK, Lin WW, Lee SS. A comprehensive investigation of antiinflammatory diarylheptanoids from the leaves of Alnus formosana. Phytochemistry 2012; 73: 84-94

[21] Yang Y, Kinoshita K, Koyama K. Structure-antiemetic-activity of some diarylheptanoids and their analogues. Phytomedicine 2002; 9: 146-152 